\title{
Feeding behavior, spatial distribution and phylogenetic affinities of the heterotrophic dinoflagellate Oxyphysis oxytoxoides
}

\author{
Myung Gil Park ${ }^{1}$, Hwayoung Lee ${ }^{1}$, Kwang Young Kim ${ }^{1}$, Sunju Kim ${ }^{2, *}$ \\ ${ }^{1}$ Department of Oceanography, Chonnam National University, Gwangju 500-757, Republic of Korea \\ ${ }^{2}$ Smithsonian Environmental Research Center, 647 Contees Wharf Road, Edgewater, Maryland 21037, USA
}

\begin{abstract}
We documented the abundance of the heterotrophic dinoflagellate Oxyphysis oxytoxoides Kofoid along the Korean coast, cultured it (food source: the marine ciliate Myrionecta rubra Jankowski [= Mesodinium rubrum Lohmann]), sequenced its nuclear-encoded large-subunit (LSU) rDNA, and resolved its phylogenetic relationship within the Dinophysiales. Abundance was low, usually $<9.7 \times 10^{3}$ cells ${ }^{-1}$, in samples from 2005 and 2006. It co-occurred with the mixotrophic dinoflagellate Dinophysis acuminata, possibly indicating a common pool of prey. Growth on M. rubra reached a density of $38 \times 10^{5}$ cells $\mathrm{l}^{-1}$. Observations on live cells from our established cultures revealed that $O$. oxytoxoides uses a peduncle to suck up the cell contents of $M$. rubra, the number of food vacuoles increasing as feeding proceeds. No regional variability was found in partial LSU rDNA sequences (domains D1-D2) of our strains, despite different sampling sites and dates. Phylogenetic analysis, based on LSU rDNA, showed that while Amphisolenia forms an early divergent basal group in the Dinophysiales, the other dinophysoids form 2 separate groups: (1) Oxyphysis and Phalacroma and (2) Histioneis, Ornithocercus, Citharistes and Dinophysis. The presence of a peduncle in several genera, and the widespread distribution of pedunculate dinophysoids, indicate that these species may be fundamentally heterotrophic with a common feeding mechanism. Our results shed light on the feeding ecology and phylogenetic position of O. oxytoxoides.
\end{abstract}

KEY WORDS: Dinophysiales · Myrionecta rubra - Oxyphysis oxytoxoides · Peduncle feeding · Phylogeny

\section{INTRODUCTION}

The order Dinophysiales (Dinophyceae) is a group of thecate dinoflagellates exhibiting a highly diverse morphology and trophic mode. This order consists of 3 families - Amphisoleniaceae, Dinophysiaceae and Oxyphysiaceae-which contain 12 genera and 282 species (Fensome et al. 1993, Steidinger \& Tangen 1996, Gómez 2005). While the genus Dinophysis includes 104 species, which are more than in any of the other genera, the genera Metaphalacroma and Oxyphysis each contain only 1 species (Gómez 2005). Although species belonging to the Dinophysiales show worldwide distribution in the marine environment, some genera show a restricted distribution pattern; for example, genera such as Ornithocercus and Histioneis are confined to tropical waters, and Oxyphysis is restricted to the North Pacific (Foissner 2006, Taylor et al. 2008).

The genus Oxyphysis was usually included in the Amphisoleniaceae (e.g. Schiller 1933, Loeblich 1982) until Sournia (1984) separated it into its own family. The family Oxyphysiaceae is characterized by the location of the ventral pore at the apex, unlike the families Amphisoleniaceae and Dinophysiaceae in which the pore is situated ventrally (Fensome et al. 1993). The family currently contains $O$. oxytoxoides only (as a type species), which is a laterally compressed, moder- 
ately elongate, and thecate heterotrophic species (Kofoid 1926). Our knowledge of the ecophysiology, life cycle and molecular phylogeny of $O$. oxytoxoides is limited, although its feeding mechanism and behavior have been reported (Inoue et al. 1993).

Intergeneric relationships within the Dinophysiales have received much attention over the past $\sim 80 \mathrm{yr}$. Due to its structural similarities with the genus Oxytoxum, Kofoid (1926) considered the genus Oxyphysis as a possible link between the orders Dinophysiales and Peridiniales. Kofoid \& Skogsberg (1928) proposed, for the first time, a hypothetical evolutionary radiation for the dinophysoids, based on information about structural resemblance and degree of specialization in thecal morphology. Abé (1967) considered that the elongate genera Amphisolenia and Triposolenia arose from the genus Oxyphysis. Taylor (1980) proposed that genera such as Metaphalacroma, Pseudophalacroma, Oxyphysis, Proheteroschisma and Heteroschisma exhibit morphological experimentation of the apical plate region and represent several short lines rather than a continuing evolutionary sequence. Very recently, Jensen \& Daugbjerg (2009) examined the phylogenetic relationships among 6 genera (Amphisolenia, Citharistes, Dinophysis, Histioneis, Ornithocercus and Phalacroma) based on LSU rDNA sequences and-based on compiled information from Kofoid \& Skogsberg (1928), Tai \& Skogsberg (1934), Taylor (1980) and Hallegraeff \& Lucas (1988) - hypothesized that Oxyphysis radiated from Metaphalacroma. Handy et al. (2009) addressed relationships among 4 genera (Dinophysis, Histioneis, Ornithocercus and Phalacroma) in the Dinophysiaceae based on rDNA sequences. None of these studies, however, included O. oxytoxoides in the phylogenetic analysis to resolve intergeneric relationships among genera in the order Dinophysiales.

The objectives of this study were (1) to document the spatial distribution of the heterotrophic dinoflagellate Oxyphysis oxytoxoides along the Korean coasts, (2) to establish $O$. oxytoxoides in culture with the ciliate prey Myrionecta rubra, (3) to sequence the nuclear-encoded LSU rDNA of our Korean strains of O. oxytoxoides (and to check for any regional variations), and (4) to resolve the phylogenetic relationship of $O$. oxytoxoides within the order Dinophysiales.

\section{MATERIALS AND METHODS}

Sampling. Samples were taken from 15 sites along the Korean coast (Fig. 1) during the following periods: 26 to 30 July, 24 to 27 August and 23 to 26 September 2005, and 11 to 14 May 2006. During each of the sampling periods, samples were collected from all of the 15 sites. During each sampling, surface water samples

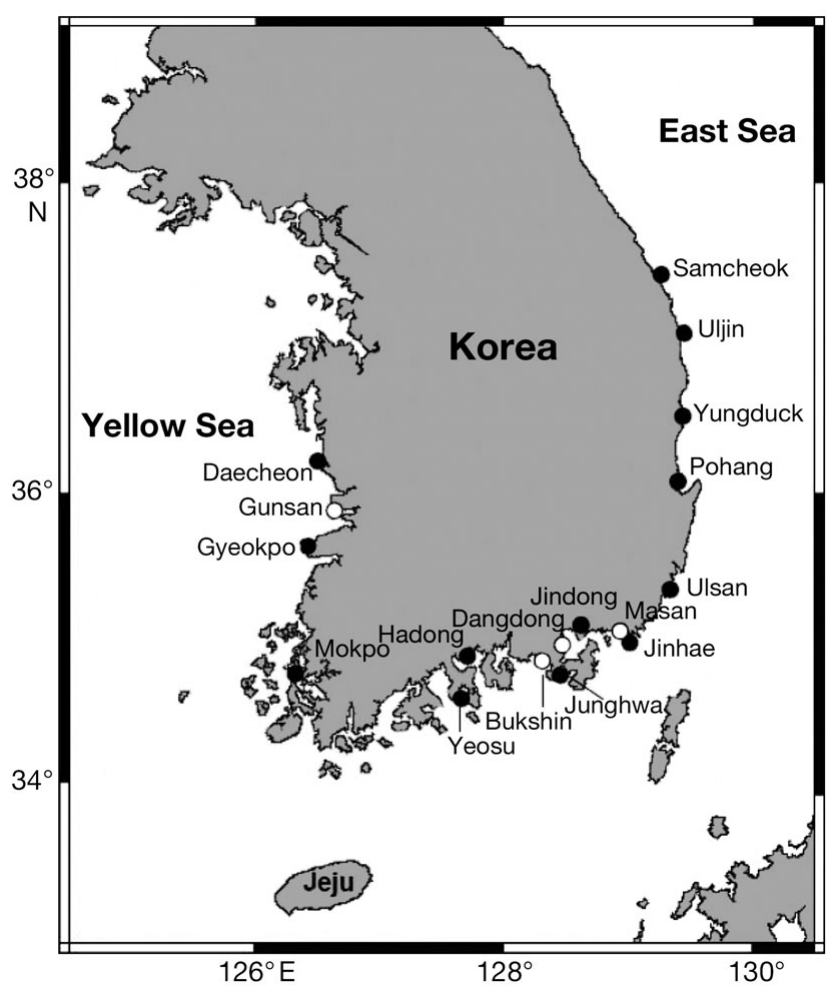

Fig. 1. Sampling sites along the Korean coasts. Open circles indicate sites where samples for single-cell PCR were also collected

(300 ml) were collected using a bucket and then immediately fixed with acidic Lugol's solution (2\% final conc.).

Cell isolation and cultures. Seawater samples for establishing cultures, and for carrying out single-cell polymerase chain reaction (PCR), were collected using a $20 \mu \mathrm{m}$ plankton net from 4 sites in September and December 2009 (Fig. 1, Table 1). Oxyphysis oxytoxoides cells ( 1 to 6 cells per sampling site) were isolated from the concentrated plankton samples using drawn Pasteur glass pipets under an inverted microscope (Olympus model IX51) or a stereomicroscope (Olympus model SZX7). The isolated single cells were used for either setting up cultures or as templates for singlecell PCR to determine a partial LSU rDNA sequence (see 'DNA extraction, PCR amplification and DNA sequencing' below). To establish cultures, individual cells were first washed at least 5 times in GF/F-filtered, autoclaved seawater and then transferred into 6-well Nunc plates (Nunclon $^{\mathrm{TM}}$ ) containing $3 \mathrm{ml}$ of $\mathrm{f} / 2-\mathrm{Si}$ medium with salinity 30 ( $+5 \% \mathrm{v} / \mathrm{v}$ soil extract). Then, the ciliate Myrionecta rubra strain MR-MAL01, which was grown using the cryptophyte strain CR-LOHABE01 as prey, was provided at a concentration of about 1000 cells $\mathrm{ml}^{-1}$ as a food source for O. oxytoxoides. All cultures used in this study were maintained at $20^{\circ} \mathrm{C}$ on 
Table 1. Summary of position of sampling sites, sampling dates, salinity, water temperature, and numbers of Oxyphysis oxytoxoides cells isolated for single-cell PCR along the Korean coasts. nd: not determined

\begin{tabular}{|c|c|c|c|c|c|c|}
\hline $\begin{array}{l}\text { Sampling } \\
\text { sites }\end{array}$ & $\begin{array}{l}\text { Latitude } \\
\left({ }^{\circ} \mathrm{N}\right)\end{array}$ & $\begin{array}{l}\text { Longitude } \\
\left({ }^{\circ} \mathrm{E}\right)\end{array}$ & $\begin{array}{c}\text { Sampling } \\
\text { dates (2009) }\end{array}$ & $\begin{array}{l}\text { Salinity } \\
\text { (psu) }\end{array}$ & $\begin{array}{c}\text { Temperature } \\
\left({ }^{\circ} \mathrm{C}\right)\end{array}$ & $\begin{array}{l}\text { No. of cells } \\
\text { isolated }\end{array}$ \\
\hline Gunsan & $35^{\circ} 56^{\prime} 16^{\prime \prime}$ & $126^{\circ} 31^{\prime} 45^{\prime \prime}$ & Sep 11 & 31.0 & 25.5 & 1 \\
\hline Bukshin & $34^{\circ} 51^{\prime} 34^{\prime \prime}$ & $128^{\circ} 25^{\prime} 08^{\prime \prime}$ & Sep 19 & 28.2 & 25.6 & 5 \\
\hline Dangdong & $34^{\circ} 59^{\prime} 21^{\prime \prime}$ & $128^{\circ} 24^{\prime} 29^{\prime \prime}$ & Sep 11 & 29.8 & 26.3 & 3 \\
\hline \multirow[t]{3}{*}{ Masan } & $35^{\circ} 12^{\prime} 04^{\prime \prime}$ & $128^{\circ} 34^{\prime} 42^{\prime \prime}$ & Sep 11 & 27.7 & 24.7 & 6 \\
\hline & & & Sep 19 & 30.6 & 24.0 & 3 \\
\hline & & & Dec 28 & 31.6 & nd & 1 \\
\hline
\end{tabular}

a 14 h light:10 h dark cycle, with cool-white fluorescent lamps providing $50 \mu \mathrm{mol}$ photons $\mathrm{m}^{-2} \mathrm{~s}^{-1}$.

Cell enumeration and microscopy. For enumeration of heterotrophic Oxyphysis oxytoxoides and mixotrophic Dinophysis acuminata, Lugol's-fixed samples were first concentrated 6 -fold to $50 \mathrm{ml} ; 1 \mathrm{ml}$ of the concentrated samples was then loaded into a SedgeWick Rafter chamber and whole area of the chamber was scanned.

Live observations of the feeding process were made in a 6-well plate using an Olympus IX51 microscope at $400 \times$ magnification and recorded with a Sony Progressive 3CCD color video camera attached to a digital image time-lapse recording system (TCS Korea). Video sequences were frame-grabbed, and individual frames were exported in BMP format. Bright-field and epifluorescence micrographs of live cells or Lugol'sfixed cells were taken at $1000 \times$ magnification using a digital camera (PowerShot G5) coupled to the Olympus BX51 microscope equipped with differential interference contrast and fluorescence cube (U-MWB2, 450 to $480 \mathrm{~nm}$ excitation, $500 \mathrm{~nm}$ emission).

DNA extraction, PCR amplification and DNA sequencing. Single-cell PCR technique was used to obtain partial LSU rDNA sequences. Individual Oxyphysis oxytoxoides cells isolated from each sampling site (Table 1) were put into $10 \mu \mathrm{l}$ of Tris-EDTA (TE) buffer ( $\mathrm{pH}$ 8.0). The cells were then heated to $95^{\circ} \mathrm{C}$ for $10 \mathrm{~min}$ to achieve cell lysis. One microliter of each heat-treated specimen was used as a template to amplify the LSU rDNA (D1-D3 region). Amplification of LSU rDNA was performed using a primer set, D1R (5'-ACC CGC TGA ATT TAA GCA TA-3') and D3B (5' TCG GAG GGA ACC AGC TAC TA-3') (Hansen et al. 2000). The PCR reaction mixture $(25 \mu \mathrm{l})$ consisted of $1 \mu \mathrm{l}$ of template DNA, $0.5 \mu \mathrm{l}$ of a $10 \mathrm{mM}$ solution of each dNTP, $1 \mu$ of $10 \mathrm{mM}$ primers, $2.5 \mu \mathrm{l}$ of $10 \times$ Taq buffer $\left(\right.$ Diastar $^{\mathrm{TM}}$ ), and 0.6 unit of Taq DNA polymerase (Dias$\left.\operatorname{tar}^{\mathrm{TM}}\right)$. The PCR reaction was performed using MyGenie ${ }^{\mathrm{TM}} 96$ Gradient Thermal Block (Bioneer) according to the following protocol: an initial denaturation step at $94^{\circ} \mathrm{C}$ for $4 \mathrm{~min}, 35$ cycles at $94^{\circ} \mathrm{C}$ for $1 \mathrm{~min}, 43^{\circ} \mathrm{C}$ for $50 \mathrm{~s}$ and $72^{\circ} \mathrm{C}$ for $1.5 \mathrm{~min}$; we used a post-extension step of $72^{\circ} \mathrm{C}$ for $5 \mathrm{~min}$. The size of the PCR products was $\sim 1 \mathrm{~kb}$ when analyzed by electrophoresis in $1.5 \%$ agarose gels and visualized with ethidium bromide. The amplified products were directly sequenced using the same primer set for PCR, D1R and D3B. Sequencing was performed with an Applied Biosystems automated sequencer (ABI 3730xl) at Macrogen Corp, Seoul, Korea. The LSU rDNA sequences have been deposited in GenBank under accession numbers HM563682 and HQ131916.

Phylogenetic analysis. The LSU rDNA sequences were compared to the sequences of closely related taxa within the Dinophysiales obtained from the GenBank database using a BLAST search. Prorocentrum micans and $P$. minimum were used as an outgroup, since prorocentroids and dinophysoids not only appear to be derived from peridinioids (Taylor 2004), but also share several unique morphological characters, including the sagittal suture and the megacystic growth zone (Fensome et al. 1993). Sequences including 59 in-group taxa and the 2 outgroup taxa were aligned using ClustalX v.1.83 (Thompson et al. 1997) and manually adjusted using MacClade v.4.08 (Maddison \& Maddison 2002). The alignment was trimmed to 747 positions (D1-D2 region) for phylogenetic analysis. Phylogenetic trees were inferred using maximum likelihood (ML) and Baysian inference. Modeltest v.3.7 (Posada \& Crandall 1998) was used to select the most appropriate model of substitution for the ML method, run with PAUP* v.4b10 (Swofford 2003). The $\mathrm{GTR}+\mathrm{I}+\Gamma(-\operatorname{lnL}=8575.6182, \mathrm{I}=0.1440, \mathrm{G}=0.7642)$ model was selected as the best-fit model for the dataset. ML analysis was performed using RAxML (Stamatakis 2006) with the rapid bootstrapping option and 1000 replicates. Baysian analysis was run with MrBayes v.3.1.2 (Ronquist \& Huelsenbeck 2003). Posterior probability was determined in 2 runs, each with 4 Markov Chain Monte Carlo (MCMC) processes for 10 million generations, sampled every 100 generations, and followed a burn-in of 1 million generations. The MCMC output files were checked for stationarity with Tracer v.1.5 (http://tree.bio.ed.ac.uk/ software/tracer/). 


\section{RESULTS}

\section{Abundance of Oxyphysis oxytoxoides in Korean coastal waters}

The abundance of Oxyphysis oxytoxoides ranged from

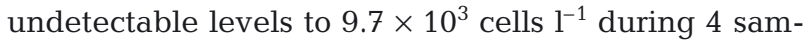
pling periods (Fig. 2A). Except for August 2005, when $O$. oxytoxoides was not observed across all sampling sites, the highest cell concentrations were always found at Masan. During the same period, the abundance of Dinophysis acuminata ranged from undetectable levels to $11.5 \times 10^{3}$ cells $^{-1}$ (Fig. 2B). The highest cell concentrations of $D$. acuminata were also found at Masan.

\section{Cultivation of Oxyphysis oxytoxoides}

When grown in a salinty $30 \mathrm{f} / 2-\mathrm{Si}$ medium at $20^{\circ} \mathrm{C}$ in a $14 \mathrm{~h}$ light:10 h dark cycle $\left(50 \mu \mathrm{mol}\right.$ photons $\left.\mathrm{m}^{-2} \mathrm{~s}^{-1}\right)$ and supplied with the marine ciliate Myrionecta rubra
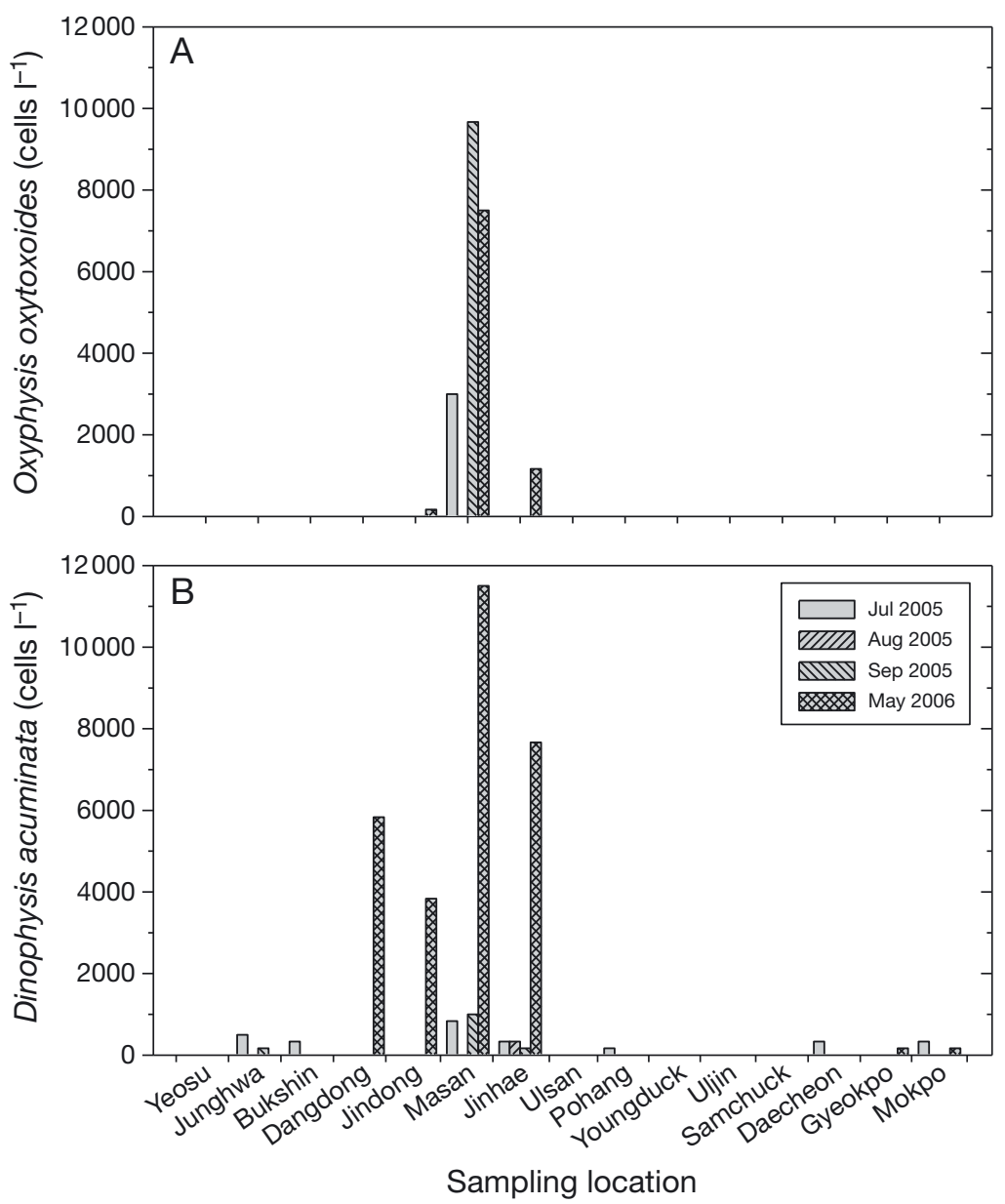

Fig. 2. Oxyphysis oxytoxoides and Dinophysis acuminata. Abundance of (A) O. oxytoxoides and (B) D. acuminata at each of the sampling sites during July, August and September 2005 and May 2006 as prey, Oxyphysis oxytoxoides grew well (Fig. 3A). We managed to maintain the culture under these growth conditions for $\sim 5 \mathrm{mo}$, after which, unfortunately, we lost the culture due to an accident. During cultivation, the highest cell density was $38 \times 10^{5}$ cells $1^{-1}$. No sustained growth was observed in the absence of the ciliate prey.

\section{Feeding}

Observations of live cells under the microscope, using cells from our established cultures, revealed that the nutritional mode of Oxyphysis oxytoxoides was phagotrophy by myzocytosis (Fig. 3B,C). The ciliate Myrionecta rubra, with pronounced jumping behavior, was captured upon mechanical contact. After making physical contact, O. oxytoxoides pierced $M$. rubra with a peduncle (Fig. 3B, see video available as supplementary material online at www.int-res.com/articles/suppl/ a062p279_supp/). Once the ciliate had been trapped, the dinoflagellate swam around towing the attached ciliate. At that time, O. oxytoxoides started gradually to consume the ciliate. During the early stage of feeding (i.e. capturing of prey and swimming), most cilia were shed from the ciliate's body (Fig. 3C). During feeding, O. oxytoxoides sucked out the contents of the prey using a peduncle that extended from the flagellar pore. As the feeding process proceeded, the number of food vacuoles increased within the O. oxytoxoides cell (Fig. 4). Epifluorescence microscopy revealed that the food vacuoles within $O$. oxytoxoides emitted bright yellow-orange fluorescence under blue-light excitation (Fig. 4B,C), typical of cryptophycean phycobilin (phycoerythrin).

\section{LSU rDNA sequences}

The partial LSU rDNA (domains D1-D3; 917 nucleotides) of Oxyphysis oxytoxoides was successfully amplified from a total of 19 individual cells. All but 1 of the sequences was identical, in spite of 4 different sampling sites and dates. One exception was found for a cell isolated from Gunsan coastal water, which differed from the other isolates by only 1 nucleotide. The sequences from our isolates were also identical to the O. oxytoxoides sequence (accession no. EF613359) deposited in the GenBank database (Kim \& Kim 2007). 

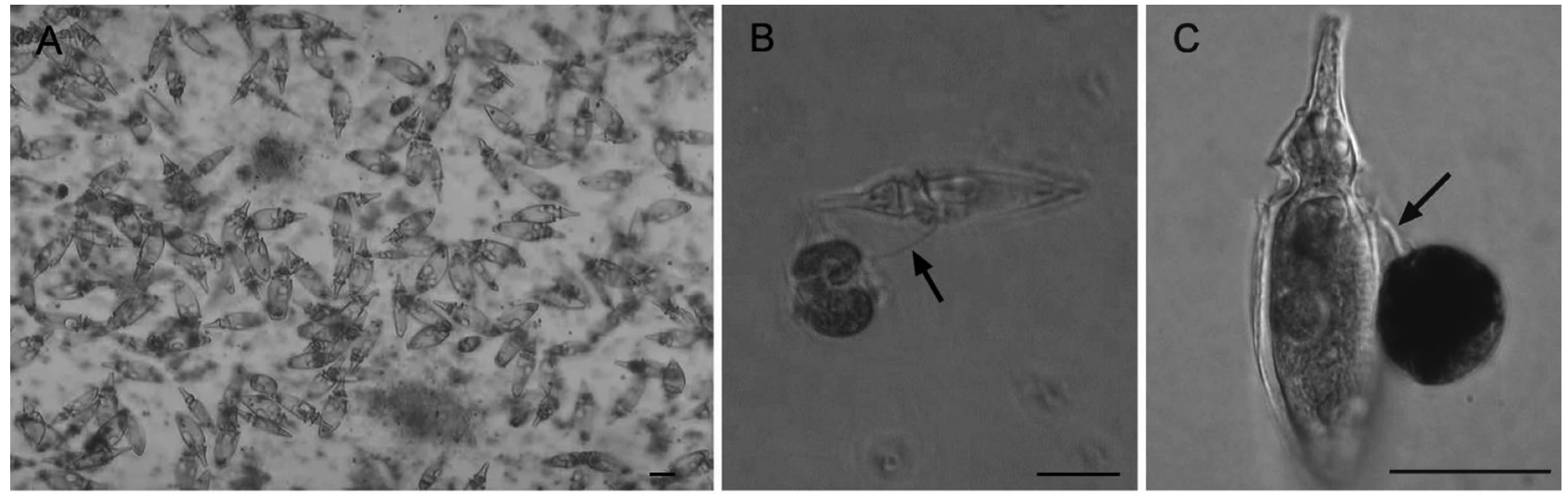

Fig. 3. Oxyphysis oxytoxoides. Live cells of (A) a culture grown on the ciliate Myrionecta rubra as prey during this study, (B) $O$. oxytoxoides with a recently captured $M$. rubra prey organism, and (C) peduncle-feeding (myzocytosis) on $M$. rubra. Arrows indicate a peduncle extending from the flagellar pore. Scale bars $=20 \mu \mathrm{m}$

\section{Phylogenetic analyses}

The phylogenetic analyses of 59 in-group taxa of Dinophysiales and 2 outgroup taxa were performed on
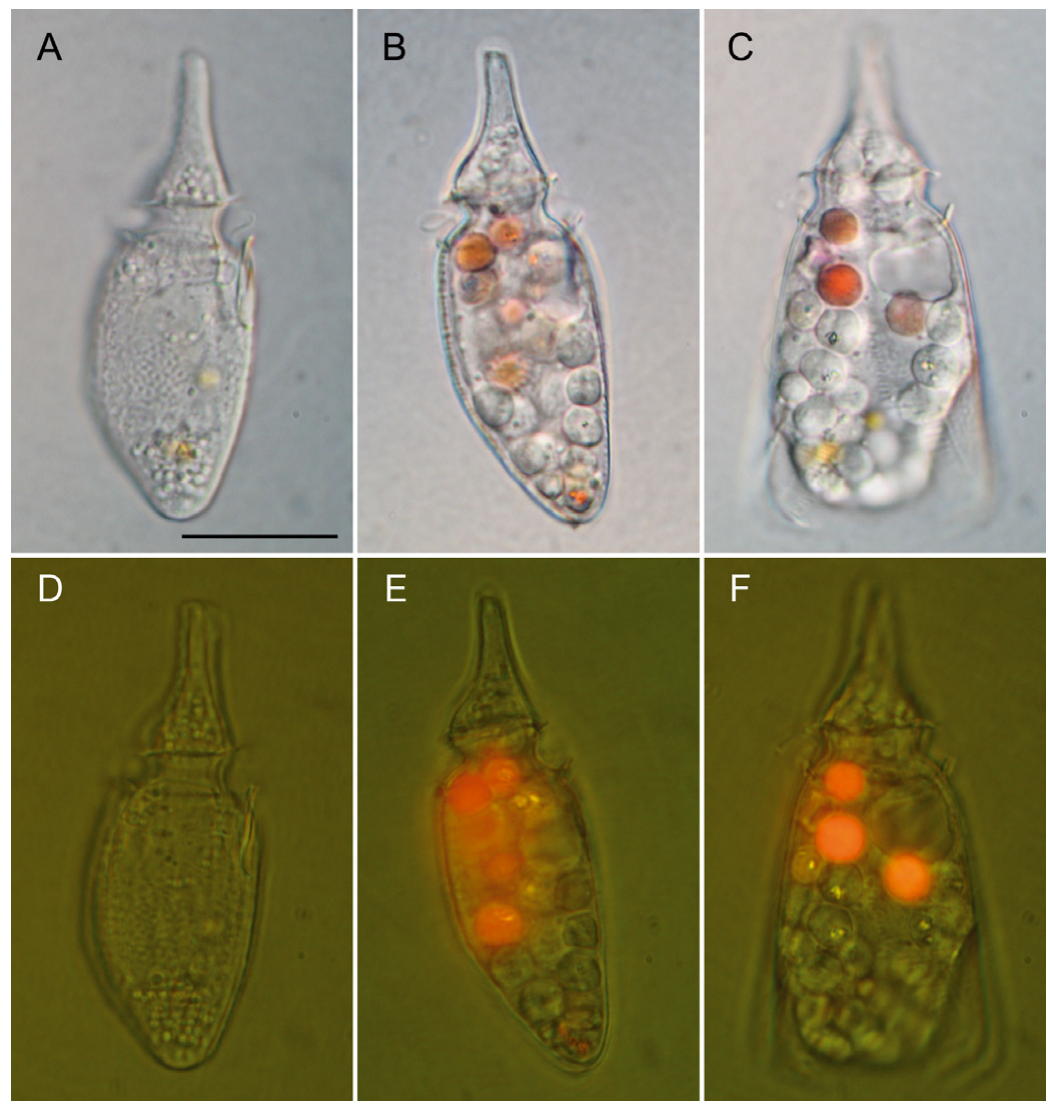

Fig. 4. Oxyphysis oxytoxoides. (A-C) Light and (D-F) epifluorescence micrographs of live cells $(A)$ with no food vacuoles, and $(B, C)$ with several food vacuoles within the cell. Note that some food vacuoles are filled with orange fluorescent plastids derived from the ciliate prey Myrionecta rubra. Scale bar = $20 \mu \mathrm{m}$. The scale in (A) applies to all panels the basis of partial LSU rDNA, including the D1-D2 domains $(747 \mathrm{bp})$. The optimal tree yielded by Bayesian analysis is shown in Fig. 5. The tree topologies of most major groups were largely congruent with the maximum likelihood (ML) tree, although discrepancies were found in a few branches.

The Amphisolenia species formed a strongly supported basal clade (Clade A) with a $100 \%$ ML bootstrap value and a posterior probability (PP) of 1 . The remaining dinophysoids divided into 2 highly supported groups labeled Clade B and Clade C, respectively. Clade B was strongly supported by an ML bootstrap value of $98 \%$ and PP of 1 and included Oxyphysis oxytoxoides and Phalacroma species, except for $P$. apicatum and $P$. cfr. argus. O. oxytoxoides clustered with $P$. acutum and the type species $P$. porodictyum, but the relationship was not well supported (an ML bootstrap value of $50 \%$ and PP of 0.53). Clade C formed by Histioneis, Ornithocercus, Citharistes, Dinophysis and 2 Phalacroma species (P. apicatum and $P$. cfr. argus) was moderately supported by a PP of 1 and an ML bootstrap value of $83 \%$, but the relationship between the genera was not well resolved. Interestingly, $P$. apicatum and $P$. cf. argus were distantly related to the other Phalacroma species in Clade B. It is unclear whether the genus Dinophysis is monophyletic, as species belonging to the genus formed 4 lineages within Clade C. 


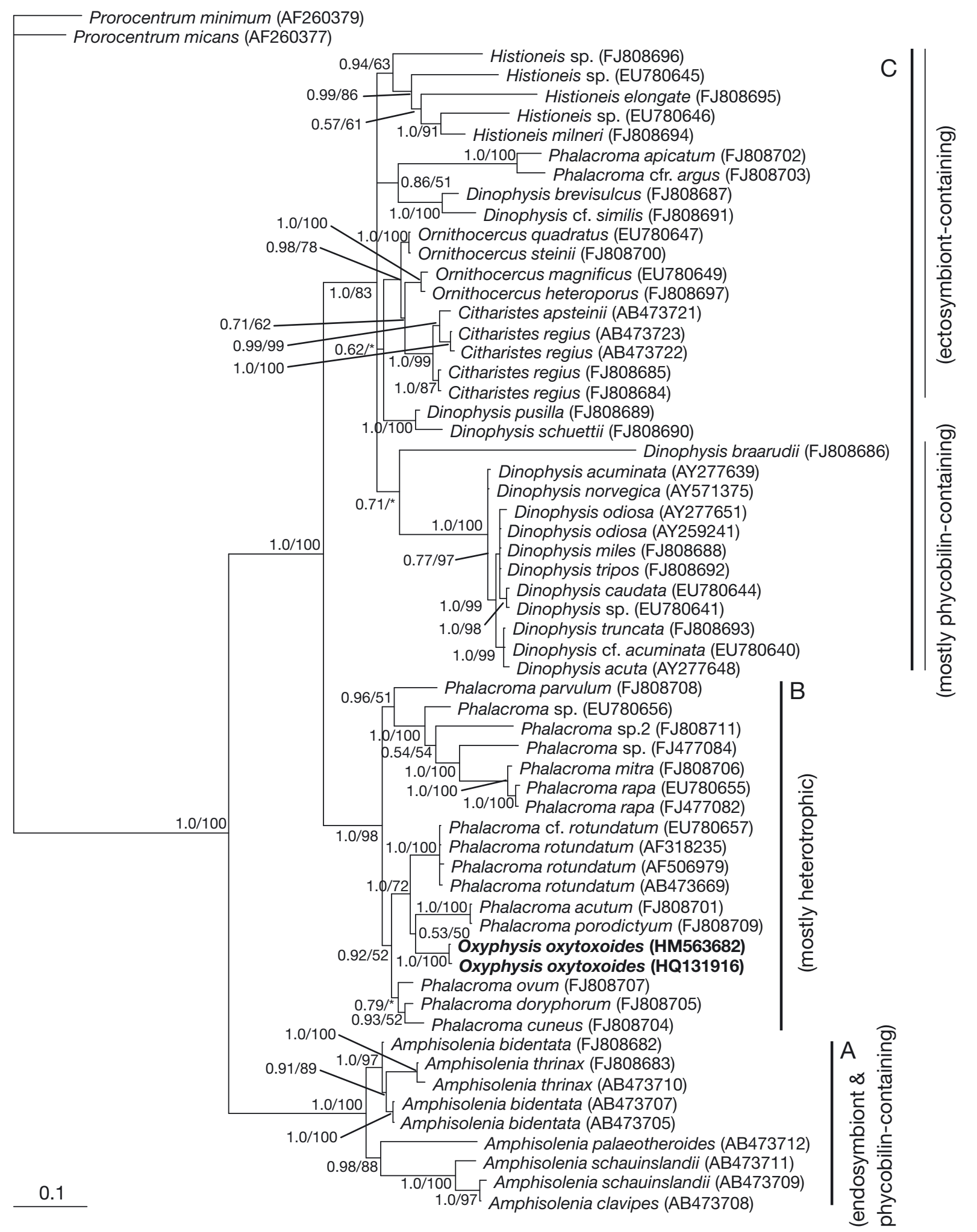

Fig. 5. Phylogenetic tree of 59 in-group taxa of Dinophysiales species and 2 outgroup taxa of prorocentroids inferred from Bayesian analysis based on large-subunit (LSU) rDNA (domains D1-D2) sequences (747 bases). LSU rDNA sequences from Oxyphysis oxytoxoides determined in this study are in bold. Supports over nodes are indicated as Bayesian posterior probabilities/ML bootstraps (100 replicates). *: Bootstrap values of $<50 \%$. GenBank accession numbers are shown in parentheses 
According to the phylogenetic analyses, Clades A and $\mathrm{C}$ included species containing phycobilin-pigmented endosymbionts (Amphisolenia) (Lucas 1991, Tarangkoon et al. 2010), cyanobacterial ectosymbionts (Histioneis, Ornithocercus and Citharistes) (Carpenter 2002, Tarangkoon et al. 2010), or mixotrophic species having phycobilin pigment (Dinophysis) (Park et al. 2006, 2008), whereas Clade B contained mostly heterotrophic species (Oxyphysis and Phalacroma) (present study; Inoue et al. 1993, Jensen \& Daugbjerg 2009).

\section{DISCUSSION}

\section{Feeding and food source}

To our knowledge, this is the first report of extended cultivation of Oxyphysis oxytoxoides using the marine ciliate Myrionecta rubra as prey. The heterotrophic dinoflagellate $O$. oxytoxoides occurs usually in low numbers (less than a few cells per ml) in coastal marine environments (e.g. Nakane et al. 2008). Indeed, during the field sampling along the Korean coasts between 2005 and 2006, we observed maximum cell densities of

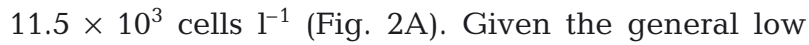
abundance of $O$. oxytoxoides in natural environments, cell densities $\left(38 \times 10^{5}\right.$ cells $\left.1^{-1}\right)$ obtained in culture established in this study are remarkable, suggesting that the mixotrophic ciliate $M$. rubra may be an appropriate prey for developing cultures of the heterotrophic dinoflagellate. More interestingly, O. oxytoxoides often co-occurred with the mixotrophic dinoflagellate Dinophysis acuminata in field samples, indicating that both dinoflagellates may be feeding on a common pool of prey (e.g. the ciliate M. rubra). Indeed, Park et al. (2006, 2008) and several subsequent studies (e.g. Nagai et al. 2008, Nishitani et al. 2008) showed that mixotrophic Dinophysis species grow well when provided with the ciliate $M$. rubra as prey, as $O$. oxytoxoides did in the present study. Given that $M$. rubra is a cosmopolitan species (Taylor et al. 1971, Lindholm 1985), our result indicates that, in addition to mixotrophic Dinophysis spp. and heterotrophic O. oxytoxoides, other dinophysoids might feed on this ciliate as a common food source either to meet nutritional demands or to acquire kleptoplastids.

In addition to Oxyphysis oxytoxoides, several other dinophysoids have been observed feeding on ciliates using a peduncle. For example, Hansen (1991) found that the heterotrophic species Phalacroma rotundatum (known as Dinophysis rotundata; Jensen \& Daugbjerg 2009) and Dinophysis hastata were able to feed on the ciliate Tiarina fusus by myzocytosis. As in the present study, Inoue et al. (1993) also observed that O. oxytox- oides fed on loricate and non-loricate ciliates by the use of a peduncle. Mixotrophic Dinophysis spp. were also observed feeding on Myrionecta rubra by myzocytosis (Park et al. 2006, 2008, Nagai et al. 2008, Nishitani et al. 2008). Very recently, Tarangkoon et al. (2010) observed, with transmission electron microscopy, that Ornithocercus magnificus and Ornithocercus quadratus have a peduncle. Further, they observed that Ornithocercus spp. contained numerous food vacuoles with trichocyst-like remnants that most likely originated from an ingested ciliate. While myzocytosis is also common in numerous species belonging to Peridiniales (e.g. Pfiesteria spp.; Lewitus et al. 1999), subsequent findings of the presence of a peduncle for several genera, as well as widespread distribution of the species having a peduncle across Clades B and C within the dinophysoids, indicate that species belonging to the dinophysoids may be fundamentally heterotrophic (Schnepf \& Elbrächter 1988) with a common feeding mechanism.

From evolutionary and ecological points of view, several questions still remain open. For example, despite having a common feeding mechanism (i.e. peduncle feeding), why do mixotrophic Dinophysis species and heterotrophic Oxyphysis not treat the plastids obtained from the ciliate prey $M$. rubra in the same way? The mixotrophic Dinophysis species are known to feed on the ciliate prey Myrionecta rubra and actively retain its plastids (i.e. kleptoplastidy; Nagai et al. 2008, Park et al. 2006, 2008, Minnhagen et al. 2011), whereas the heterotrophic Oxyphysis feeds on the same prey but digests the plastids. Does Dinophysis have an ability to discern the plastids from the rest of the ingested prey? Or, does Oxyphysis not yet have the ability to retain the plastids from the prey? From an ecological point of view, it would be interesting to test whether Oxyphysis can successfully compete with Dinophysis for a common ciliate prey, M. rubra, and whether Oxyphysis can survive on other prey. Addressing these questions in the future will improve our knowledge of plastid evolution and will help us to better understand complex biological interactions of protistan planktonic food webs.

\section{Phylogenetic relationships}

Our phylogenetic analyses including Oxyphysis oxytoxoides did not greatly affect the overall topology of the Dinophysiales obtained by Jensen \& Daugbjerg (2009) and Handy et al. (2009): while Amphisolenia formed an early divergent basal group, the remaining dinophysoids diverged into 2 separate groups, the first formed of Oxyphysis and Phalacroma, the second of Histioneis, Ornithocercus, Citharistes and Dino- 
physis. Abé (1967) believed that the elongate genera Amphisolenia and Triposolenia evolved from the genus Oxyphysis. Taylor (1980) considered genera such as Metaphalacroma, Pseudophalacroma, Oxyphysis, Proheteroschisma and Heteroschisma to represent several short lines rather than a continuing evolutionary sequence as in the Dinophysis-Ornithocercus-Citharistes-Histioneis series. Jensen \& Daugbjerg (2009) hypothesized that Oxyphysis radiates from Metaphalacroma, based on compiled information from previous studies. However, it seems unlikely that $O$. oxytoxoides diverged early from the ancestor of the dinophysoids, which was hypothesized when based only on morphology in the previous studies. Rather, our phylogenetic analyses showed that $O$. oxytoxoides shared a more recent common ancestor with Phalacroma species than with other dinoflagellates.

On the other hand, it is noteworthy that Clade B, formed of Oxyphysis and Phalacroma species, contained mostly heterotrophic species, except for Phalacroma mitra, which was recently reported to contain kleptoplastids of haptophyte origin (Koike et al. 2005), and $P$. rapa, which is known to contain chloroplasts whose nature has not yet been determined-i.e. are they true, permanent chloroplasts or kleptoplastids derived from chrysophyte or prymnesiophyte symbionts (Hallegraeff \& Lucas 1988)? Aside from Clade B, the other 2 clades (A and C) are characterized by the presence of phycobilin-containing plastids or cyanobacterial endo- (or ecto-)symbionts, although eukaryotic endosymbionts within Amphisolenia and Triposolenia have also been observed (Tarangkoon et al. 2010). Taylor (2004) thought that the phycobilin-containing dinophysoids Dinophysis, Amphisolenia and Triposolenia seemed more closely related to each other than to more morphologically complex (i.e. more elaborate in shape and size of the cingular and sulcal lists) genera such as Ornithocercus, Histioneis and Citharistes. However, our phylogenetic analysis suggests that the phycobilin-containing dinophysoids are not monophyletic, which also agrees with the phylogenetic analyses made by Handy et al. (2009) and Jensen \& Daugbjerg (2009).

Sinophysis is thought to be an ancestor of the dinophysoids (Taylor 1980) and is known to host numerous cyanobacterial symbionts (Escalera et al. 2010). Thus, it may be likely that species belonging to the dinophysoids, which once had symbionts, may be skillful in feeding on, or having symbiotic relationships with, phycobilin-containing microalgae (cyanobacteria and cryptophyte). This may partly explain why dinophysoids are highly specialized in either having phycobilin-pigmented plastids or hosting cyanobacterial symbionts.
Acknowledgements. This work was supported by the National Research Foundation of Korea (NRF) grant funded by the Korean government (MEST) (No. 2007-0055898) to K.Y.K and a National Research Foundation of Korea grant funded by the Korean Government (2009-0066796) to M.G.P. We thank Prof. Wonho Yih for allowing us to use the strain of Myrionecta rubra as a food source during this study. We also thank the 3 anonymous reviewers, whose comments and suggestions greatly improved the manuscript.

\section{LITERATURE CITED}

Abé TH (1967) The armoured Dinoflagellata: II. Prorocentridae and Dinophysidae (A). Publ Seto Mar Biol Lab 14: 369-389

Carpenter EJ (2002) Marine cyanobacterial symbioses. Biol Environ 102:15-18

Escalera L, Reguera B, Takishita K, Yoshimatsu S, Koike K, Koike K (2010) Cyanobacterial endosymbionts in the benthic dinoflagellate Sinophysis canaliculata (Dinophysiales, Dinophyceae). Protist doi:10.1016/j.protis.2010.07.003

Fensome RA, Taylor FJR, Norris G, Sarjeant WAS, Wharton DI, Williams GL (1993) A classification of living and fossil dinoflagellates. In: Micropaleontology, Special Publ 7, Sheridan Press, Hanover, PA

Foissner W (2006) Biogeography and dispersal of microorganisms: a review emphasizing protists. Acta Protozool 45:111-136

Gómez F (2005) A list of free-living dinoflagellate species in the world's oceans. Acta Bot Croat 64:129-212

Hallegraeff GM, Lucas IAN (1988) The marine dinoflagellate genus Dinophysis (Dinophyceae): photosynthetic, neritic and non-photosynthetic, oceanic species. Phycologia 27:25-42

Handy SM, Bachvaroff TR, Timme RE, Coats DW, Kim S, Delwiche CF (2009) Phylogeny of four dinophysiacean genera (Dinophyceae, Dinophysiales) based on rDNA sequences from single cells and environmental samples. J Phycol 45: 1163-1174

Hansen G, Daugbjerg N, Henriksen P (2000) Comparative study of Gymnodinium mikimotoi and Gymnodinium aureolum comb. nov. (=Gyrodinium aureolum) based on morphology, pigment composition, and molecular data. J Phycol 36:394-410

> Hansen PJ (1991) Dinophysis - a planktonic dinoflagellate genus which can act both as a prey and a predator of a ciliate. Mar Ecol Prog Ser 69:201-204

Inoue H, Fukuyo Y, Nimura Y (1993) Feeding behavior of dinoflagellate, Oxyphysis oxytoxoides, on ciliates. Bull Plankton Soc Jpn 40:9-17

Jensen MH, Daugbjerg N (2009) Molecular phylogeny of selected species of the order Dinophysiales (Dinophyceae) - testing the hypothesis of a dinophysioid radiation. J Phycol 45:1136-1152

Kim KY, Kim CH (2007) Phylogenetic relationships among diverse dinoflagellate species occurring in coastal waters off Korea inferred from large subunit ribosomal DNA sequence data. Algae 22:57-67

Kofoid CA (1926) On Oxyphysis oxytoxoides gen. nov., sp. nov. A dinophysoid dinoflagellate convergent toward the peridinioid type. Univ Calif Publ Zool 28:203-216

Kofoid CA, Skogsberg T (1928) The dinoflagellata: the dinophysoidae. Mem Mus Comp Zool Harvard 51:1-766

Koike K, Sekiguchi H, Kobiyama A, Takishita K, Kawachi M, Koike K, Ogata T (2005) A novel type of kleptoplastidy in Dinophysis (Dinophyceae): presence of haptophyte-type plastid in Dinophysis mitra. Protist 156:225-237 
Lewitus AJ, Glasgow HB, Burkholder JM (1999) Kleptoplastidy in the toxic dinoflagellate Pfiesteria piscicida (Dinophyceae). J Phycol 35:303-312

Lindholm T (1985) Mesodinium rubrum - a unique photosynthetic ciliate. Adv Aquat Microbiol 3:1-48

Loeblich AR III (1982) Dinophyceae. In: Parker SP (ed) Synopsis and classification of living organisms. McGraw-Hill, New York, NY p 101-115

Lucas IAN (1991) Symbionts of the tropical Dinophysiales (Dinophyceae). Ophelia 33:213-224

Maddison WP, Maddison DR (2002) MacClade: analysis of phylogeny and character evolution. Sinauer, Sunderland, MA

Minnhagen S, Kim M, Salomon P, Yih W, Graneli E, Park MG (2011) Active uptake of kleptoplastids by Dinophysis caudata from its ciliate prey Myrionecta rubra. Aquat Microb Ecol 62:99-108

Nagai S, Nitshitani G, Tomaru Y, Sakiyama S, Kamiyama T (2008) Predation by the toxic dinoflagellate Dinophysis fortii on the ciliate Myrionecta rubra and observation of sequestration of ciliate chloroplasts. J Phycol 44:909-922

Nakane T, Nakaka K, Bouman H, Platt T (2008) Environmental control of short-term variation in the plankton community of inner Tokyo Bay, Japan. Estuar Coast Shelf Sci 78: 796-810

Nishitani G, Nagai S, Sakiyama S, Kamiyama T (2008) Successful cultivation of the toxic dinoflagellate Dinophysis caudata (Dinophyceae). Plankton Benthos Res 3:78-85

Park MG, Kim S, Kim HS, Myung G, Kang YG, Yih W (2006) First successful culture of the marine dinoflagellate Dinophysis acuminata. Aquat Microb Ecol 45:101-106

Park MG, Park JS, Kim M, Yih W (2008) Plastid dynamics during survival of Dinophysis caudata without its ciliate prey. J Phycol 44:1154-1163

Posada D, Crandall KA (1998) MODELTEST: testing the model of DNA substitution. Bioinformatics 14:817-818

Ronquist F, Huelsenbeck JP (2003) MrBayes 3: Bayesian phylogenetic inference under mixed models. Bioinformatics 19:1572-1574

Schiller J (1933) Dinoflagellatae (Peridineae) in monographis-

Editorial responsibility: Robert Sanders,

Philadelphia, Pennsylvania, USA cher Behandlung. In: Rabenhorst L (ed) KryptogamenFlora von Deutschland, Österreich und der Schweiz. Akademische Verlagsgesellschaft, Leipzig

Schnepf E, Elbrächter M (1988) Cryptophycean-like double membrane-bound chloroplast in the dinoflagellate, Dinophysis Ehrenb: evolutionary, phylogenetic and toxicological implications. Bot Acta 101:196-203

Sournia A (1984) Classification et nomenclature de divers dinoflagellés marins (Dinophyceae). Phycologia 23:345-355

Stamatakis A (2006) RAxML-VI-HPC: maximum likelihoodbased phylogenetic analyses with thousands of taxa and mixed models. Bioinformatics 22:2688-2690

Steidinger KA, Tangen K (1996) Dinoflagellates. In: Tomas CR (ed) Identifying marine phytoplankton. Academic Press, San Diego, CA, p 387-598

Swofford DL (2003) PAUP*. Phylogenetic analysis using parsimony $\left({ }^{*}\right.$ and other methods). Version $4.0 \mathrm{~b} 10$. Sinauer, Sunderland, MA

Tai LS, Skogsberg T (1934) Studies on the Dinophysoidae, marine armored dinoflagellates, of Monterey Bay, California. Arch Protistenkd 82:380-482

Tarangkoon W, Hansen G, Hansen PJ (2010) Spatial distribution of symbiont-bearing dinoflagellates in the Indian Ocean in relation to oceanographic regimes. Aquat Microb Ecol 58:197-213

Taylor FJR (1980) On dinoflagellate evolution. Biosystems 13: 65-108

Taylor FJR (2004) Illumination or confusion? Dinoflagellate molecular phylogenetic data viewed from a primarily morphological standpoint. Phycol Res 52:308-324

Taylor FJR, Blackbourn DJ, Blackbourn J (1971) The redwater ciliate Mesodinium rubrum and its 'incomplete symbionts': a review including new ultrastructural observations. J Fish Res Board Can 28:391-407

Taylor FJR, Hoppenrath M, Saldarriaga JF (2008) Dinoflagellate diversity and distribution. Biodivers Conserv 17:407-418

Thompson JD, Gibson TJ, Plewniak F, Jeanmougin F, Higgins DG (1997) The ClustalX windows interface: flexible strategies for multiple sequence alignment aided by quality analysis tools. Nucleic Acids Res 25:4876-4882

Submitted: May 6, 2010; Accepted: November 6, 2010

Proofs received from author(s): January 27, 2011 